\title{
WYKAZ ORZECZNICTWA SĄDÓW UNIJNYCH W SPRAWACH ŚRODOWISKA I JEGO OCHRONY ZA OKRES WRZESIEŃ 2011-WRZESIEŃ 2012
}

W okresie wrzesień 2011-wrzesień 2012 zapadło 28 wyroków sądów unijnych, zakwalifikowanych w repertorium orzecznictwa Trybunału Sprawiedliwości UE jako orzeczenia w zakresie problematyki „Środowisko, zrównoważony rozwoju i klimat"1. Orzeczenia te nie są jeszcze opublikowane w Zbiorze Orzeczeń Trybunału, jakkolwiek są dostępne na stronie TS UE, która została podana w wykazie jako podstawowe źródło. Sentencje orzeczeń opublikowane zostały również w Dzienniku Urzędowym UE w serii C.

Analizując tematykę poszczególnych orzeczeń sądów unijnych wydanych w omawianym okresie można wskazać na sześć grup, w których zostały też one ujęte w poniższym wykazie. W pierwszej grupie znalazło się pięć wyroków dotyczących

* Doktor nauk prawnych, adiunkt w Katedrze Prawa Ochrony Środowiska, Wydział Prawa i Administracji, Uniwersytet Mikołaja Kopernika.

1 Zob. plan systematyki repertorium TS UE po traktacie lizbońskim - pozycja 4 „Polityka wewnętrzna UE”, pozycja 4.23 - „Środowiska, zrównoważonego rozwoju i klimatu”; http://curia.eu. 
gospodarki odpadami (w tym również kwestia ścieków i przemieszczania odpadów), zaś w grupie kolejnej ujętych zostało sześć orzeczeń dotyczących problematyki oceny oddziaływania na środowisko. W grupie trzeciej natomiast znalazło się sześć wyroków dotyczących ochrony przyrody, przy czym część z nich dotyczy w pewnym zakresie jednocześnie problematyki oceny oddziaływania na środowisko (to jest sprawa C-404/09 Komisja Europejska przeciwko Królestwu Hiszpanii oraz sprawa C-560/08 Komisja Europejska przeciwko Królestwu Hiszpanii). W czwartej grupie ujęte zostały cztery wyroki dotyczące ochrony klimatu, a ściślej rzecz biorąc - systemu handlu uprawnieniami do emisji gazów cieplarnianych. Piąta grupa to orzeczenia dotyczące problematyki partycypacji społecznej w ochronie środowiska, w których to wyrokach sądy unijne dokonały wykładni przepisów unijnych w związku z przepisami konwencji z Aarhus ${ }^{2}$. W ostatniej grupie ujęte zostały pojedyncze wyroki dotyczące takich zagadnień jak: poważne awarie, zintegrowane zapobieganie zanieczyszczeniom i ich kontrola, biopaliwa oraz GMO. Orzeczenia w poszczególnych grupach tematycznych wykazu zostały uporządkowane chronologicznie.

Warto też zauważyć, że w wykazie dotyczącym okresu wrzesień 2011 - wrzesień 2012 znalazły się trzy wyroki w sprawach, w których Rzeczpospolita Polska była stroną i jeden wyrok w sprawie, w której była ona interwenientem. Będąc więc stro-

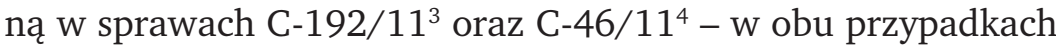
z zakresu ochrony przyrody - Polska została uznana za państwo uchybiające zobowiązaniom traktatowym. Natomiast w sprawie C-504/09P ${ }^{5}$, której przedmiotem było odwołanie Komisji od wyroku Sądu w sprawie T-183/07 Rzeczpospolita Polska prze-

2 Konwencja sporządzona w Aarhus dnia 25 czerwca 1998 r. o dostępie do informacji, udziale społeczeństwa w podejmowaniu decyzji oraz dostępie do sprawiedliwości w sprawach dotyczących środowiska, Dz. U. 2003 r. Nr 78, poz. 706.

3 Zob. pozycję III.4. wykazu (Ochrona przyrody).

4 Zob. pozycję III. 6 wykazu (Ochrona przyrody).

5 Zob. pozycję IV. 3 wykazu (Ochrona klimatu). 
ciwko Komisji Europejskiej ${ }^{6}$, Polska wraz z innymi państwami (Węgrami, Litwą, Słowacją oraz Wielką Brytanią) obroniła swoje stanowisko odnośnie krajowego planu rozdziału uprawnień do emisji gazów cieplarnianych. Z kolei będąc interwenientem w sprawie C-560/08 Komisja Europejska przeciwko Królestwu Hiszpanii ${ }^{7}$ Polska popierała stanowisko pozwanej Hiszpanii, która jednakże sprawę przegrała.

\section{GOSPODARKA ODPADAMI}

\section{I.1. WYROK TRYBUNAEU (CZWARTA IZBA) Z DNIA 10 LISTOPADA 2011 R. W SPRAWIE C-405/10 POSTĘPOWANIE KARNE PRZECIWKO ÖZLEMOWI GARENFELDOWI ${ }^{8}$}

Przedmiot: wniosek o wydanie orzeczenia w trybie prejudycjalnym - Amtsgericht Bruchsal - Wykładnia art. 37 rozporządzenia (WE) nr 1013/2006 Parlamentu Europejskiego i Rady z dnia 14 czerwca 2006 r. w sprawie przemieszczania odpadów (Dz. U. L 190, s. 1) oraz rozporządzenia Komisji (WE) nr 1418/2007 z dnia 29 listopada 2007 r. dotyczącego wywozu w celu poddania odzyskowi niektórych odpadów wymienionych w załączniku III lub IIIA rozporządzenia (WE) nr 1013/2006 Parlamentu Europejskiego i Rady do pewnych państw, których nie obowiązuje decyzja OECD w sprawie kontroli transgranicznego przemieszczania odpadów (Dz. U. L 316, s. 6) - Zakaz wywozu odpadów przeznaczonych do odzysku objętych kodem B1120 (katalizatory) do Libanu

Sentencja: Artykuł 36 ust. 1 lit. f) i art. 37 rozporządzenia (WE) nr 1013/2006 Parlamentu Europejskiego i Rady z dnia

6 Wyrok Sądu pierwszej instancji (druga izba) z dnia 23 września 2009 r. Rzeczpospolita Polska przeciwko Komisji Wspólnot Europejskich, Zb. Orz. TE [2009] II-03395.

7 Zob. pozycję III.3. wykazu (Ochrona przyrody).

8 Opubl.: http://curia.eu. 
14 czerwca 2006 r. w sprawie przemieszczania odpadów w związku z rozporządzeniem Komisji (WE) nr 1418/2007 z dnia 29 listopada 2007 r. dotyczącym wywozu w celu poddania odzyskowi niektórych odpadów wymienionych $\mathbf{w}$ załączniku III lub IIIA do rozporządzenia (WE) nr 1013/2006 Parlamentu Europejskiego i Rady do pewnych państw, których nie obowiązuje decyzja OECD w sprawie kontroli transgranicznego przemieszczania odpadów, zmienionym rozporządzeniem Komisji (WE) nr 740/2008 z dnia 29 lipca 2008 r., należy interpretować w ten sposób, że wywóz z Unii Europejskiej do Libanu odpadów przeznaczonych do odzysku objętych kodem B1120 zawartym w wykazie B części 1 załącznika V do rozporządzenia nr 1013/2006 jest zakazany.

\section{I.2. WYROK TRYBUNAŁU (OSMA IZBA) Z DNIA 1 GRUDNIA 2011 R. W SPRAWIE C-515/10 KOMISJA EUROPEJSKA PRZECIWKO REPUBLICE FRANCUSKIEJ ${ }^{9}$}

Przedmiot: uchybienie zobowiązaniom państwa członkowskiego - Nieprawidłowa transpozycja art. 2 lit. e), art. 3 ust. 1 i art. 6 lit. d) dyrektywy Rady 1999/31/WE z dnia 26 kwietnia 1999 r. w sprawie składowania odpadów (Dz. U. L 182, s. 1) oraz przepisów załącznika do decyzji Rady 2003/33/WE z dnia 19 grudnia 2002 r. ustanawiającej kryteria i procedury przyjęcia odpadów na składowiska, na podstawie art. 16 i załącznika II do dyrektywy 1999/31/WE (Dz. U. L 11, s. 27) - Przepisy krajowe przewidujące kategorię odpadów „obojętnych i niebezpiecznych" niezgodne z dyrektywą - Składowanie odpadów azbestowo-cementowych

Sentencja: 1) Nie przyjmując przepisów ustawowych, wykonawczych i administracyjnych koniecznych do zapewnienia, by odpady azbestowo-cementowe były poddawane obróbce na przeznaczonych do tego składowiskach, Republika Francuska uchybiła zobowiązaniom, które na niej ciążą na mocy art. 2 lit. e), art. 3 ust. 1 oraz art. 6 lit. d) dyrekty- 
wy Rady 1999/31/WE z dnia 26 kwietnia 1999 r. w sprawie składowania odpadów oraz przepisów załącznika do decyzji Rady 2003/33/WE z dnia 19 grudnia 2002 r. ustanawiającej kryteria i procedury przyjęcia odpadów na składowiska, na podstawie art. 16 i załącznika II do dyrektywy 1999/31.

2) Republika Francuska zostaje obciążona kosztami postępowania.

\section{I.3. WYROK TRYBUNAEU (CZWARTA IZBA) Z DNIA 29 MARCA 2012 R. W SPRAWIE C-1/11 INTERSEROH SCRAP AND METAL TRADING GMBH PRZECIWKO SONDERABFALL-MANAGEMENT-GESELLSCHAFT RHEINLAND-PFALZ MBH (SAM) ${ }^{10}$}

Przedmiot: wniosek o wydanie orzeczenia w trybie prejudycjalnym - Verwaltungsgericht Mainz - Wykładnia art. 18 ust. 1 i 4 rozporządzenia (WE) nr 1013/2006 Parlamentu Europejskiego i Rady z dnia 14 czerwca 2006 r. w sprawie przemieszczania odpadów (Dz. U. L 190, s. 1) - Dokument zawarty w załączniku VII do rzeczonego rozporządzenia, zawierający informacje towarzyszące przemieszczaniu niektórych odpadów - Prawo pośrednika do niewskazania w dokumencie tożsamości wytwórców odpadów w celu ochrony swoich klientów wobec odbiorcy

Sentencja: 1) Artykuł 18 ust. 4 rozporządzenia (WE) nr 1013/2006 Parlamentu Europejskiego i Rady z dnia 14 czerwca 2006 r. w sprawie przemieszczania odpadów, zmienionego rozporządzeniem Komisji (WE) nr 308/2009 z dnia 15 kwietnia 2009 r., należy interpretować w ten sposób, że nie pozwala on handlowcowi-pośrednikowi będącemu podmiotem organizującym przemieszczanie odpadów na nieujawnienie tożsamości wytwórcy odpadów ich odbiorcy, jak ustanowiono w art. 18 ust. 1 w związku z załącznikiem VII do tego rozporządzenia, nawet jeżeli to nieujawnienie byłoby konieczne do ochrony tajemnicy handlowej tego handlowca-pośrednika.

10 Opubl.: http://curia.eu. 
2) Artykuł 18 ust. 1 rozporządzenia $\mathrm{nr}$ 1013/2006, zmienionego rozporządzeniem $\mathrm{nr} 308 / 2009$, należy interpretować $\mathrm{w}$ ten sposób, że zobowiązuje on $\mathrm{w}$ ramach przemieszczania odpadów objętego tym przepisem handlowca-pośrednika do wypełnienia pola 6 dokumentu określonego w załączniku VII do rozporządzenia nr 1013/2006, zmienionego rozporządzeniem $\mathrm{nr} 308 / 2009$, i do przekazania go odbiorcy, przy czym zakres tego obowiązku nie może być ograniczony przez prawo do ochrony tajemnicy handlowej.

\section{I.4. WYROK TRYBUNAŁU (CZWARTA IZBA) Z DNIA 24 MAJA 2012 R. W SPRAWIE C-97/11 AMIA SPA, W LIKWIDACJI PRZECIWKO PROVINCIA REGIONALE DI PALERMO ${ }^{11}$}

Przedmiot: wniosek o wydanie orzeczenia w trybie prejudycjalnym - Commissione Tributaria Provinciale di Palermo - Wykładnia art. 10 dyrektywy Rady 1999/31/WE z dnia 26 kwietnia 1999 r. w sprawie składowania odpadów (Dz. U. L 182, s. 1), dyrektywy 2000/35/WE Parlamentu Europejskiego i Rady z dnia 29 czerwca 2000 r. w sprawie zwalczania opóźnień w płatnościach w transakcjach handlowych (Dz. U. L 200, s. 35) - Uregulowanie krajowe ustanawiające szczególny podatek za umieszczanie odpadów stałych na składowisku i zobowiązujące podmiot zajmujący się składowiskiem do uiszczenia (tytułem zaliczki) tegoż podatku, którego kwota jest ustalana na podstawie ilości składowanych odpadów i który jest należny od podmiotu, który umieszcza odpady na składowisku.

Sentencja: W takich okolicznościach jak te przed sądem krajowym:

- przed podjęciem decyzji o niestosowaniu właściwych przepisów ustawy nr 549 z dnia 28 grudnia 1995 r. o środkach racjonalizacji finansów publicznych do sądu krajowego należy najpierw sprawdzenie, z uwzględnieniem wszystkich przepisów prawa wewnętrznego, zarówno materialnego, jak i proce-

11 Opubl.: http://curia.eu. 
duralnego, czy w żadnym wypadku nie uda mu się dokonać wykładni prawa krajowego umożliwiającej rozstrzygnięcie zawisłego przed nim sporu w sposób zgodny z brzmieniem i celami dyrektywy Rady 1999/31/WE z dnia 26 kwietnia 1999 r. w sprawie składowania odpadów, zmienionej rozporządzeniem (WE) nr 1882/2003 Parlamentu Europejskiego i Rady z dnia 29 września 2003 r., oraz dyrektywy 2000/35/WE Parlamentu Europejskiego i Rady z dnia 29 czerwca 2000 r. w sprawie zwalczania opóźnień w płatnościach w transakcjach handlowych,

- jeżeli taka wykładnia nie jest możliwa, sąd krajowy jest obowiązany nie stosować $w$ zawisłym przed nim sporze przepisów krajowych sprzecznych $\mathrm{z}$ art. 10 dyrektywy 1999/31, zmienionej rozporządzeniem nr 1882/2003, i z art. 1-3 dyrektywy 2000/3.

\section{I.5. WYROK TRYBUNAŁU (SIÓDMA IZBA) Z DNIA 19 LIPCA 2012 R. W SPRAWIE C-565/10 KOMISJA EUROPEJSKA PRZECIWKO REPUBLICE WŁOSKIEJ ${ }^{12}$}

Przedmiot: Uchybienie zobowiązaniom państwa członkowskiego - Naruszenie art. 3, 4 i 10 dyrektywy Rady 91/271/ EWG z dnia 21 maja 1991 r. dotyczącej oczyszczania ścieków komunalnych (Dz. U. L 135, s. 40)

Sentencja: 1) Nie wydając przepisów koniecznych w celu zapewnienia:

- by aglomeracje Acri, Siderno, Bagnara Calabra, Bianco, Castrovillari, Crotone, Santa Maria del Cedro, Lamezia Terme, Mesoraca, Montebello Ionico, Motta San Giovanni, Reggio Calabria, Rende, Rossano, Scalea, Sellia Marina, Soverato, Strongoli (Kalabria), Cervignano del Friuli (Friuli-Wenecja Julijska), Frascati (Lacjum), Porto Cesareo, Supersano, Taviano (Apulia), Misterbianco i inne, Aci Catena, Adra- 
no, Catania i inne, Giarre-Mascali-Riposto $i$ inne, Caltagirone, Aci Castello, Acireale i inne, Belpasso, Gravina di Catania, Tremestieri Etneo, San Giovanni La Punta, Agrigento i jej przedmieścia, Porto Empedocle, Sciacca, Cefalù, Carini i ASI Palermo, Palermo i sąsiednich obszarów, Santa Flavia, Augusta, Priolo Gargallo, Carlentini, Scoglitti, Marsala, Messina 1, Messina i Messina 6 (Sycylia), których równoważna liczba mieszkańców wynosi ponad 15000 i które odprowadzają ścieki do wód nieuznawanych za „obszary wrażliwe” w rozumieniu art. 5 dyrektywy Rady 91/271/EWG z dnia 21 maja 1991 r. dotyczącej oczyszczania ścieków komunalnych, zmienionej rozporządzeniem (WE) nr 1137/2008 Parlamentu Europejskiego i Rady z dnia 22 października 2008 r., były wyposażone $\mathrm{w}$ systemy zbierania ścieków komunalnych zgodnie $\mathrm{z}$ art. 3 tej dyrektywy,

- by w aglomeracjach Lanciano-Castel Frentano (Abruzja), Acri, Siderno, Bagnara Calabra, Castrovillari, Crotone, Montebello Ionico, Motta San Giovanni, Reggio Calabria, Rossano (Kalabria), Battipaglia, Benevento, Capaccio, Capri, Ischia, Casamicciola Terme, Forio, Massa Lubrense, Napoli Est, Vico Equense (Kampania), Trieste-Muggia-San Dorligo (Friuli-Wenecja Julijska), Albenga, Borghetto Santo Spirito, Finale Ligure, Imperia, Santa Margherita Ligure, Quinto, Rapallo, Recco, Riva Ligure (Liguria), Casamassima, Casarano, Porto Cesareo, San Vito dei Normanni, Supersano (Pulia), Misterbianco i innych, Scordia-Militello Val di Catania, Palagonia, Aci Catena, Giarre-Mascali-Riposto i innych, Caltagirone, Aci Castello, Acireale i innych, Belpasso, Gravina di Catania, Tremestieri Etneo, San Giovanni La Punta, Macchitella, Niscemi, Riesi, Agrigento i jej przedmieściach, Favara, Palma di Montechiaro, Menfi, Porto Empedocle, Ribera, Sciacca, Bagheria, Cefalù, Carini i ASI Palermo, Misilmeri, Monreale, Santa Flavia, Termini Imerese, Trabia, Augusta, Avola, Carlenti- 
ni, Ragusa, Scicli, Scoglitti, Campobello di Mazara, Castelvetrano 1, Triscina Marinella, Marsala, Mazara del Vallo, Barcellona Pozzo di Gotto, Capo d'Orlando, Furnari, Giardini Naxos, Consortile Letojanni, Pace del Mela, Piraino, Roccalumera, Consortile Sant'Agata Militello, Consortile Torregrotta, Gioiosa Marea, Messina 1, Messina 6, Milazzo, Patti i de Rometta (Sycylia), których równoważna liczba mieszkańców wynosi ponad 15000 i które odprowadzają ścieki do wód nieuznawanych za „obszary wrażliwe” w rozumieniu art. 5 dyrektywy 91/271, zmienionej rozporządzeniem $\mathrm{nr}$ 1137/2008, ścieki komunalne odprowadzane do systemów zbierania były poddawane oczyszczaniu zgodnemu z przepisami art. 4 ust. 1 i 3 tej dyrektywy, i

- by oczyszczalnie ścieków komunalnych budowane w celu spełnienia wymogów przewidzianych w art. 4-7 dyrektywy 91/271, zmienionej rozporządzeniem nr 1137/2008, były projektowane, budowane, wykorzystywane $\mathrm{i}$ utrzymywane $\mathrm{w}$ sposób zapewniający wystarczającą wydajność we wszystkich normalnych warunkach klimatycznych miejsca, w jakim są one położone, oraz by oczyszczalnie ścieków były projektowane $\mathrm{w}$ sposób uwzględniający sezonowe zmiany obciążenia w aglomeracjach Lanciano-Castel Frentano (Abruzja), Acri, Siderno, Bagnara Calabra, Castrovillari, Crotone, Montebello Ionico, Motta San Giovanni, Reggio Calabria, Rossano (Kalabria), Battipaglia, Benevento, Capaccio, Capri, Ischia, Casamicciola Terme, Forio, Massa Lubrense, Napoli Est, Vico Equense (Kampania), Trieste-Muggia-San Dorligo (Friuli-Wenecja Julijska), Albenga, Borghetto Santo Spirito, Finale Ligure, Imperia, Santa Margherita Ligure, Quinto, Rapallo, Recco, Riva Ligure (Liguria), Casamassima, Casarano, Porto Cesareo, San Vito dei Normanni, Supersano (Pulia), Misterbianco i innych, Scordia-Militello Val di Catania, Palagonia, Aci Catena, Giarre-Mascali-Riposto i innych, Caltagirone, Aci Ca- 
stello, Acireale i innych, Belpasso, Gravina di Catania, Tremestieri Etneo, San Giovanni La Punta, Macchitella, Niscemi, Riesi, Agrigento i jej przedmieściach, Favara, Palma di Montechiaro, Menfi, Porto Empedocle, Ribera, Sciacca, Bagheria, Cefalù, Carini i ASI Palermo, Misilmeri, Monreale, Santa Flavia, Termini Imerese, Trabia, Augusta, Avola, Carlentini, Ragusa, Scicli, Scoglitti, Campobello di Mazara, Castelvetrano 1, Triscina Marinella, Marsala, Mazara del Vallo, Barcellona Pozzo di Gotto, Capo d'Orlando, Furnari, Giardini Naxos, Consortile Letojanni, Pace del Mela, Piraino, Roccalumera, Consortile Sant'Agata Militello, Consortile Torregrotta, Gioiosa Marea, Messina 1, Messina 6, Milazzo, Patti i Rometta (Sycylia),

Republika Włoska uchybiła zobowiązaniom, które na niej ciążą na mocy art. 3, art. 4 ust. 1 i 3 oraz art. 10 dyrektywy 91/271, zmienionej rozporządzeniem nr 1137/2008.

2) Republika Włoska zostaje obciążona kosztami postępowania.

\section{OCENA ODDZIAEYWANIA NA ŚRODOWISKO ${ }^{13}$}

\section{II.1. WYROK TRYBUNAŁU (CZWARTA IZBA) Z DNIA 22 WRZEŚNIA 2011 R. W SPRAWIE C-295/10 GENOVAITE் VALČIUKIENĖ, JULIJA PEKELIENE், LIETUVOS ŽALIŲJŲ JUDĖJIMAS, PETRAS GIRINSKIS, LAURYNAS ARIMANTAS LAŠAS PRZECIWKO PAKRUOJO RAJONO SAVIVALDYBĖS, ŠIAULIŲ VISUOMENĖS SVEIKATOS CENTRAS, ŠIAULIŲ REGIONO APLINKOS APSAUGOS DEPARTAMENTAS ${ }^{14}$}

Przedmiot: wniosek o wydanie orzeczenia w trybie prejudycjalnym - Lietuvos vyriausiasis administracinis teismas -

13 Zob. też sprawy: C-404/09 Komisja Europejska przeciwko Królestwu Hiszpanii, C-560/08 Komisja Europejska przeciwko Królestwu Hiszpanii, ujęte w punkcie III.2 i III.3 wykazu (Ochrona przyrody).

14 Opubl.: http://curia.eu. 
Wykładnia art. 3 i art. 11 dyrektywy 2001/42/WE Parlamentu Europejskiego i Rady z dnia 27 czerwca 2001 r. w sprawie oceny wpływu niektórych planów i programów na środowisko (Dz. U. L 197, s. 30) oraz dyrektywy Rady 85/337/EWG z dnia 27 czerwca 1985 r. w sprawie oceny wpływu wywieranego przez niektóre przedsięwzięcia publiczne i prywatne na środowisko (Dz. U. L 175, s. 40) - Wymóg przeprowadzenia oceny w ramach dyrektywy 2001/42/WE po przeprowadzeniu oceny w ramach dyrektywy 85/337/EWG - Ustawodawstwo krajowe przewidujące, że nie ma potrzeby dokonania strategicznej oceny wpływu na środowisko miejscowych planów zagospodarowania przestrzennego, jeżeli plany te dotyczą tylko jednego przedmiotu działalności gospodarczej

Sentencja: 1) Wykładni art. 3 ust. 5 dyrektywy 2001/42/ WE Parlamentu Europejskiego i Rady z dnia 27 czerwca 2001 r. w sprawie oceny wpływu niektórych planów i programów na środowisko $\mathrm{w}$ związku $\mathrm{z}$ jej art. 3 ust. 3 należy dokonywać $\mathbf{w}$ ten sposób, że przepis ten sprzeciwia się uregulowaniu krajowemu takiemu jak rozpatrywane w postępowaniu przed sądem krajowym, które przewiduje w sposób tak ogólny i bez indywidualnego zbadania każdego przypadku, iż ocena na podstawie tej dyrektywy nie jest przeprowadzana, gdy plany, które określają sposób użytkowania małych obszarów na poziomie lokalnym, dotyczą tylko jednego przedmiotu działalności.

2) Artykuł 11 ust. 1 i 2 dyrektywy 2001/42 należy interpretować $w$ ten sposób, że ocena wpływu na środowisko zrealizowana zgodnie z dyrektywą 85/337/EWG z dnia 27 czerwca 1985 r. w sprawie oceny wpływu wywieranego przez niektóre przedsięwzięcia publiczne i prywatne na środowisko, zmienioną dyrektywą Rady 97/11/WE z dnia 3 marca 1997 r., nie zwalnia $\mathrm{z}$ wymogu przeprowadzenia takiej oceny na podstawie dyrektywy 2001/42. Jednakże do sądu odsyłającego należy zbadanie, czy ocena, która została przeprowadzona na podstawie zmienionej dyrektywy 85/337, może być uznana za wyraz skoordynowanej lub wspólnej procedury i czy obejmuje ona już wszystkie wymogi dyrektywy 2001/42. Jeżeli okazałoby się, że taka sytuacja 
ma miejsce, to nie byłoby już wymagane przeprowadzenie nowej oceny zgodnie $\mathrm{z}$ tą ostatnią dyrektywą.

3) Artykuł 11 ust. 2 dyrektywy 2001/42 należy interpretować $\mathrm{w}$ ten sposób, że nie zobowiązuje on państw członkowskich do ustanowienia $\mathrm{w}$ ich systemie prawnym skoordynowanych lub wspólnych procedur, które spełniają wymogi dyrektywy 2001/42 i zmienionej dyrektywy 85/337.

\section{II.2. WYROK TRYBUNAŁU (CZWARTA IZBA) Z DNIA 20 PAŹDZIERNIKA 2011 R. W SPRAWIE C-474/10 DEPARTMENT OF THE ENVIRONMENT FOR NORTHERN IRELAND PRZECIWKO SEAPORT (NI) LTD, MAGHERAFELT DISTRICT COUNCIL, F P MCCANN (DEVELOPMENTS) LTD, YOUNGER HOMES LTD, HERON BROTHERS LTD, G SMALL CONTRACTS, CREAGH CONCRETE PRODUCTS LTD ${ }^{15}$}

Przedmiot: wniosek o wydanie orzeczenia w trybie prejudycjalnym - Court of Appeal in Northern Ireland - Wykładnia wykładni art. 6 ust. 2-4 dyrektywy 2001/42/WE Parlamentu Europejskiego i Rady z dnia 27 czerwca 2001 r. w sprawie oceny wpływu niektórych planów i programów na środowisko (Dz. U. L 197, s. 30) - Wyznaczenie do celów konsultacji organu, który może być zainteresowany wpływem na środowisko wynikającym z realizacji planów i programów - Szczegółowe zasady informowania władz i społeczeństwa oraz konsultowania się $\mathrm{z}$ nimi

Sentencja: 1) W okolicznościach takich jak w sprawie przed sądem krajowym art. 6 ust. 3 dyrektywy 2001/42/WE Parlamentu Europejskiego i Rady z dnia 27 czerwca 2001 r. w sprawie oceny wpływu niektórych planów i programów na środowisko nie wymaga, by został utworzony bądź wyznaczony inny organ konsultacyjny w rozumieniu tego przepisu, o ile w ramach organu odpowiedzialnego normalnie za przeprowadzenie konsultacji w sprawach środowiskowych i wy-

15 Opubl.: http://curia.eu. 
znaczonego jako taki podział funkcjonalny jest zorganizowany $w$ taki sposób, że wewnętrzna jednostka administracyjna tego organu dysponuje rzeczywistą autonomią, oznaczającą między innymi, iż posiada ona własne zasoby administracyjne i personalne i jest tym samym w stanie wypełnić zadania powierzone organom konsultacyjnym $w$ rozumieniu art. 6 ust. 3 tej dyrektywy, a w szczególności udzielić w sposób obiektywny swojej opinii o planie lub programie zamierzonym przez organ, do którego jest przyłączona.

2) Artykuł 6 ust. 2 dyrektywy 2001/42 należy interpretować w ten sposób, iż nie wymaga on, by terminy, w których wyznaczone organy i społeczeństwo, którego proces decyzyjny dotyczy lub może dotyczyć $w$ rozumieniu ust. 3 i 4 tego artykułu, powinny mieć możliwość wyrażenia swojej opinii o określonym projekcie planu lub programu oraz o sprawozdaniu dotyczącym wpływu takiego planu lub programu na środowisko, zostały wyznaczone w sposób wyraźny w uregulowaniu krajowym transponującym tę dyrektywę, a w konsekwencji wspomniany ust. 2 nie stoi na przeszkodzie temu, by terminy takie były ustalane każdorazowo przez organ opracowujący plan lub program. W tym ostatnim przypadku tenże ust. 2 wymaga jednak, by do celów konsultacji $\mathrm{z}$ tymi organami i społeczeństwem $\mathrm{w}$ przedmiocie danego projektu planu lub programu faktycznie ustalony termin był wystarczający i dawał im w ten sposób realną możliwość wyrażenia we właściwym czasie ich opinii o tym projekcie planu lub programu oraz o sprawozdaniu dotyczącym wpływu tego planu lub programu na środowisko.

\section{II.3. WYROK TRYBUNAŁU (WIELKA IZBA) Z DNIA 28 LUTEGO 2012 R. \\ W SPRAWIE C-41/11 INTER-ENVIRONNEMENT WALLONIE ASBL, TERRE WALLONNE ASBL PRZECIWKO RÉGION WALLONNE ${ }^{16}$}

Przedmiot: wniosek o wydanie orzeczenia w trybie prejudycjalnym - Conseil d’État (Belgia) - Ocena wpływu okre-

16 Opubl.: http://curia.eu. 
ślonych planów i programów na środowisko - Ochrona wód przed zanieczyszczeniem azotanami pochodzenia rolniczego Stwierdzenie nieważności aktu prawa krajowego uznanego za niezgodny z dyrektywą 2001/42/WE Parlamentu Europejskiego i Rady z dnia 27 czerwca 2001 r. w sprawie oceny wpływu niektórych planów i programów na środowisko (Dz. U. L 197, s. 30) - Możliwość utrzymania w mocy skutków prawnych tego aktu przez krótki okres

Sentencja: W sytuacji gdy do sądu krajowego wpływa, na podstawie prawa krajowego, skarga o stwierdzenie nieważności krajowego aktu prawnego, stanowiącego „plan” lub „program” w rozumieniu dyrektywy 2001/42/WE Parlamentu Europejskiego i Rady z dnia 27 czerwca 2001 r. w sprawie oceny wpływu niektórych planów i programów na środowisko, oraz gdy sąd ten stwierdza, że taki „plan” lub „program” został przyjęty z naruszeniem przewidzianego tą dyrektywą obowiązku dokonania wcześniejszej oceny wpływu na środowisko, sąd ten jest zobowiązany podjąć wszelkie środki o charakterze ogólnym lub szczególnym, przewidziane przez jego prawo krajowe, aby usunąć brak takiej oceny, w tym ewentualnie zawiesić lub uchylić zaskarżony „plan” lub „program”. Mając jednak na względzie szczególne okoliczności sprawy przed sądem krajowym, dopuszczalne jest, by sąd ten, tytułem wyjątku, posłużył się przepisem krajowym umożliwiającym mu utrzymanie w mocy niektórych skutków krajowego aktu prawnego, o ile:

- ten krajowy akt prawny stanowi prawidłowy środek transpozycji dyrektywy 91/676/EWG z dnia 12 grudnia 1991 r. dotyczącej ochrony wód przed zanieczyszczeniami powodowanymi przez azotany pochodzenia rolniczego;

- wydanie i wejście w życie nowego krajowego aktu prawnego stanowiącego program działania $\mathrm{w}$ rozumieniu art. 5 tej dyrektywy nie pozwoli na uniknięcie szkodliwych skutków dla środowiska wynikających ze stwierdzenia nieważności zaskarżonego aktu prawnego; 
- stwierdzenie nieważności zaskarżonego aktu prawnego skutkowałoby stworzeniem luki prawnej w zakresie transpozycji dyrektywy 91/676, co mogłoby być bardziej szkodliwe dla środowiska, w tym sensie, że stwierdzenie nieważności wspomnianego aktu oznaczałoby mniejszą ochronę wód przed zanieczyszczeniem azotanami pochodzenia rolniczego, pozostając tym samym $\mathrm{w}$ sprzeczności $\mathrm{z}$ podstawowym celem tej dyrektywy;

- utrzymanie, tytułem wyjątku, skutków takiego aktu prawnego odnosi się wyłącznie do okresu ściśle niezbędnego do przyjęcia środków pozwalających na usunięcie stwierdzonej nieprawidłowości.

\section{II.4. WYROK TRYBUNAEU (CZWARTA IZBA) Z DNIA 22 MARCA 2012 R. W SPRAWIE C-567/10 INTER-ENVIRONNEMENT BRUXELLES ASBL, PÉTITIONS-PATRIMOINE ASBL, ATELIER DE RECHERCHE ET D'ACTION URBAINES ASBL PRZECIWKO RÉGION DE BRUXELLES-CAPITALE ${ }^{17}$}

Przedmiot: wniosek o wydanie orzeczenia w trybie prejudycjalnym - Cour constitutionnelle - Wykładnia art. 2 lit. a) dyrektywy 2001/42/WE Parlamentu Europejskiego i Rady z dnia 27 czerwca 2001 r. w sprawie oceny wpływu niektórych planów i programów na środowisko (Dz. U. L 197, s. 30) - Stosowanie dyrektywy do postępowania $\mathrm{w}$ przedmiocie uchylenia w całości lub w części planu zagospodarowania przestrzennego - Wykładnia pojęcia „wymaganych planów i programów” - Wyłączenie planów, których przyjęcie nie jest obowiązkowe

Sentencja: 1) Zawarte w art. 2 lit. a) dyrektywy 2001/42/ /WE Parlamentu Europejskiego i Rady z dnia 27 czerwca 2001 r. w sprawie oceny wpływu niektórych planów i programów na środowisko pojęcie planów i programów, które są ,wymagane przez przepisy ustawowe, wykonawcze lub administracyjne", należy interpretować w ten sposób, że 
dotyczy ono również miejscowych planów zagospodarowania przestrzennego, takich jak plan, którego dotyczy uregulowanie krajowe będące przedmiotem postępowania przed sądem krajowym, przyjmowanych na podstawie CoBAT.

2) Artykuł 2 lit. a) dyrektywy 2001/42 należy interpretować $\mathrm{w}$ ten sposób, że procedura uchylenia w całości lub w części planu zagospodarowania przestrzennego, taka jak przewidziana $\mathrm{w}$ art. 58-63 code bruxellois de l'aménagement du territoire, jest co do zasady objęta zakresem stosowania tej dyrektywy, wobec czego podlega ona regułom dotyczącym oceny wpływu na środowisko przewidzianym w tej dyrektywie.

\section{II.5. WYROK TRYBUNAŁU (TRZECIA IZBA) Z DNIA 19 KWIETNIA 2012 R. W SPRAWIE C-121/11 PRO-BRAINE ASBL I IN. PRZECIWKO COMMUNE DE BRAINE-LE-CHÂTEAU ${ }^{18}$}

Przedmiot: wniosek o wydanie orzeczenia w trybie prejudycjalnym - Conseil d'État (Belgia) - Wykładnia art. 14 lit. b) dyrektywy Rady 1999/31/WE z dnia 26 kwietnia 1999 r. w sprawie składowania odpadów (Dz. U. L 182, s. 1) oraz art. 1 ust. 2 dyrektywy Rady z dnia 27 czerwca 1985 r. w sprawie oceny skutków wywieranych przez niektóre przedsięwzięcia publiczne i prywatne na środowisko naturalne 85/337/EWG (Dz. U. L 175, s. 40) - Decyzja dotycząca dalszego działania mającego zezwolenie składowiska odpadów przy braku oceny skutków wywieranych na środowisko naturalne - Pojęcie zezwolenia na inwestycję - Zakres stosowania

Sentencja: Ostateczna decyzja zezwalająca na dalsze działanie istniejącego składowiska odpadów, wydana na podstawie art. 14 lit. b) dyrektywy Rady 1999/31/WE z dnia 26 kwietnia 1999 r. w sprawie składowania odpadów, opierając się na planie zagospodarowania, stanowi „zezwolenie na inwestycję" w rozumieniu art. 1 ust. 2 dyrektywy Rady z dnia 27 czerwca 1985 r. w sprawie oceny skutków wywie-

18 Opubl.: http://curia.eu. 
ranych przez niektóre przedsięwzięcia publiczne i prywatne na środowisko naturalne 85/337/EWG, zmienionej dyrektywą 2003/35/WE Parlamentu Europejskiego i Rady z dnia 26 maja 2003 r., tylko jeżeli decyzja ta zezwala na zmianę lub rozbudowę urządzenia lub wysypiska poprzez dokonanie robót lub interwencji zmieniających jego stan fizyczny, które mogą w sposób znacząco niekorzystny oddziaływać na środowisko naturalne $\mathrm{w}$ rozumieniu pkt 13 załącznika II do wspomnianej dyrektywy 85/337 i które tym samym stanowią „przedsięwzięcie” w rozumieniu art. 1 ust. 2 tej dyrektywy.

\section{II.6. WYROK TRYBUNAŁU (OSMA IZBA) Z DNIA 21 CZERWCA 2012 R. W SPRAWIE C-177/11 SYLLOGOS ELLINON POLEODOMON KAI CHOROTAKTON PRZECIWKO YPOURGOS PERIVALLONTOS, CHOROTAXIAS \& DIMOSION ERGON, YPOURGOS OIKONOMIKON, YPOURGOS ESOTERIKON, DIMOSIAS DIOIKISIS KAI APOKENTROSIS ${ }^{19}$}

Przedmiot: wniosek o wydanie orzeczenia w trybie prejudycjalnym - Symvoulio tis Epikrateias - Wykładnia art. 3 ust. 2 lit. b) dyrektywy 2001/42/WE Parlamentu Europejskiego i Rady z dnia 27 czerwca 2001 r. w sprawie oceny wpływu niektórych planów i programów na środowisko (Dz. U. L 197, s. 30) oraz art. 6 i 7 dyrektywy 92/43/EWG z dnia 21 maja 1992 r. w sprawie ochrony siedlisk przyrodniczych oraz dzikiej fauny i flory (Dz. U. L 206, s. 7) - Przesłanka, aby dla przeprowadzenia oceny wpływu na środowisko określonego planu i programu potencjalny wpływ na specjalny obszar ochrony był znaczny - Zakres swobodnego uznania państw członkowskich

Sentencja: Wykładni art. 3 ust. 2 lit. b) dyrektywy 2001/42/WE Parlamentu Europejskiego i Rady $z$ dnia 27 czerwca 2001 r. w sprawie oceny wpływu niektórych planów i programów na środowisko należy dokonywać w ten sposób, że obowiązek przeprowadzenia w odniesieniu do 
określonego planu oceny wpływu na środowisko w rozumieniu dyrektywy Rady 92/43/EWG z dnia 21 maja 1992 r. w sprawie ochrony siedlisk przyrodniczych oraz dzikiej fauny i flory, w brzmieniu zmienionym dyrektywą Rady 2006/105/WE z dnia 20 listopada 2006 r., zależy od wystąpienia $\mathrm{w}$ przypadku takiego planu przesłanek powodujących konieczność przeprowadzenia oceny $w$ rozumieniu dyrektywy siedliskowej, w tym przesłanki, zgodnie z którą plan może $\mathrm{w}$ istotny sposób oddziaływać na dany teren. Badanie przeprowadzone w celu sprawdzenia, czy przesłanka ta jest spełniona, musi ograniczać się do ustalenia, czy na podstawie obiektywnych okoliczności nie sposób wykluczyć, że plan ten lub to przedsięwzięcie może oddziaływać $\mathrm{w}$ istotny sposób na dany teren.

\section{OCHRONA PRZYRODY}

\section{III.1. WYROK TRYBUNAEU (CZWARTA IZBA) Z DNIA 22 WRZEŚNIA \\ 2011 R. W SPRAWIE C-90/10 KOMISJA EUROPEJSKA PRZECIWKO KRÓLESTWU HISZPANII ${ }^{20}$}

Przedmiot: uchybienie zobowiązaniom państwa członkowskiego - Naruszenie art. 4 ust. 4 oraz art. 6 ust. 1 i 2 dyrektywy Rady 92/43/EWG z dnia 21 maja 1992 r. w sprawie ochrony siedlisk przyrodniczych oraz dzikiej fauny i flory (Dz. U. L 206, s. 7) - Tereny mające znaczenie dla Wspólnoty - Środki ochronne - Makaronezyjski region biogeograficzny

Sentencja: 1) Nie ustalając, na podstawie art. 4 ust. 4 dyrektywy Rady 92/43/EWG z dnia 21 maja 1992 r. w sprawie ochrony siedlisk przyrodniczych oraz dzikiej fauny i flory, działań priorytetowych dla specjalnych obszarów ochrony, będących terenami mającymi znaczenie dla Wspólnoty

20 Opubl.: http://curia.eu. 
w makaronezyjskim regionie biogeograficznym, położonych na terytorium hiszpańskim i wymienionych $w$ decyzji Komisji z dnia 28 grudnia 2001 r. w sprawie przyjęcia wykazu terenów mających znaczenie dla Wspólnoty w makaronezyjskim regionie biogeograficznym na mocy dyrektywy Rady 92/43/EWG, oraz nie tworząc, ani nie stosując, zgodnie $\mathrm{z}$ art. 6 ust. 1 i 2 dyrektywy 92/43, stosownych środków ochronnych oraz systemu ochrony, który umożliwiałby uniknięcie pogarszania stanu siedlisk przyrodniczych, jak również niepokojenia gatunków, zapewniając ochronę specjalnych obszarów ochrony obejmujących tereny wskazane w decyzji 2002/11, a położone na terytorium hiszpańskim, Królestwo Hiszpanii uchybiło zobowiązaniom, które na nim ciążą na mocy wyżej wymienionych przepisów przytoczonej dyrektywy.

2) Królestwo Hiszpanii zostaje obciążone kosztami postępowania.

3) Republika Finlandii pokrywa własne koszty.

\section{III.2. WYROK TRYBUNAEU (CZWARTA IZBA) Z DNIA 24 LISTOPADA 2011 R. W SPRAWIE C-404/09 KOMISJA EUROPEJSKA PRZECIWKO KRÓLESTWU HISZPANII ${ }^{21}$}

Przedmiot: uchybienie zobowiązaniom państwa członkowskiego - Naruszenie art. 2, 3 i 5 ust. 1 i 3 dyrektywy Rady 85/337/EWG w sprawie oceny wpływu wywieranego przez niektóre publiczne i prywatne przedsięwzięcia na środowisko, zmienionej dyrektywą 97/11/EWG (Dz. U. L 175, s. 40) oraz art. 6 ust. 3, 2 i 4 w związku z art. 7 dyrektywą Rady 92/43/EWG z dnia 21 maja 1992 r. w sprawie ochrony siedlisk przyrodniczych oraz dzikiej fauny i flory (Dz. U. L 206, s. 7) - Kopalnie odkrywkowe - Specjalna strefa ochrony „Alto Sil” (ES0000210) - Siedlisko kantabryjskiego podgatunku głuszca zwyczajnego

21 Opubl.: http://curia.eu. 
Sentencja: 1) Zezwalając na eksploatację kopalni odkrywkowych „Nueva Julia” i „Ladrones” bez uzależnienia wydania tego zezwolenia od oceny, która pozwoliłaby określić, opisać i ocenić w sposób odpowiedni bezpośrednie, pośrednie i kumulatywne skutki istniejących przedsięwzięć dotyczących eksploatacji kopalni odkrywkowych - z wyłączeniem, jeśli chodzi o niedźwiedzia brunatnego (Ursus arctos), kopalni „Ladrones” - Królestwo Hiszpanii naruszyło zobowiązania ciążące na nim na mocy art. 2,3 i 5 ust. 1 i 3 dyrektywy Rady 85/337/EWG z dnia 27 czerwca 1985 r. w sprawie oceny skutków wywieranych przez niektóre przedsięwzięcia publiczne i prywatne na środowisko naturalne (Dz. U. L 175, s. 40), zmienionej dyrektywą Rady 97/11/WE z dnia 3 marca 1997 r.

2) Od roku 2000, w którym sklasyfikowano „Alto Sil” jako obszar specjalnej ochrony na podstawie dyrektywy Rady 79/409/EWG z dnia 2 kwietnia 1979 r. w sprawie ochrony dzikiego ptactwa, zmienionej dyrektywą Komisji 97/49/CE z dnia 29 lipca 1997 r.,

- zezwalając na eksploatację kopalni odkrywkowych „Nueva Julia” i „Ladrones” bez uzależnienia tego zezwolenia od właściwej oceny skutków tych projektów, a w każdym razie bez przestrzegania warunków pozwalających na realizację projektu pomimo wiążącego się z nim zagrożenia dla głuszca zwyczajnego (Tetrao urogallus) - stanowiącego jedno $\mathrm{z}$ bogactw naturalnych uzasadniających sklasyfikowanie obszaru „Alto Sil” jako obszaru specjalnej ochrony - co mogło nastąpić w braku alternatywnych rozwiązań, ze względu na istnienie nadrzędnego interesu publicznego i po podaniu do wiadomości Komisji Europejskiej środków kompensacyjnych koniecznych dla zagwarantowania spójności z Siecią Natura 2000, oraz

- powstrzymując się od podjęcia środków koniecznych dla uniknięcia pogorszenia się siedlisk, $\mathrm{w}$ tym siedlisk gatunków, a także uniknięcia poważnego niepokojenia głuszca zwyczajnego, którego obecność 
na obszarze „Alto Sil” była powodem wyznaczenia obszaru specjalnej ochrony, spowodowanych prowadzeniem działalności przez „Feixolín”, „Salguero-Prégame-Valdesegadas”, „Fonfría”, „Ampliación de Feixolín” i „Nueva Julia”,

Królestwo Hiszpanii uchybiło w stosunku do obszaru specjalnej ochrony „Alto Sil” zobowiązaniom ciążącym na nim na mocy art. 6 ust. 2-4 dyrektywy Rady 92/43/EWG z dnia 21 maja 1992 r. w sprawie ochrony siedlisk przyrodniczych oraz dzikiej fauny i flory, w związku z art. 7 tej dyrektywy.

3) Od grudnia 2004 r., powstrzymując się od podjęcia środków koniecznych dla uniknięcia pogorszenia się siedlisk, w tym siedlisk gatunków, a także uniknięcia poważnego niepokojenia tych gatunków powodowanego przez kopalnie „Feixolín”, „Fonfría” i „Ampliación de Feixolín” Królestwo Hiszpanii uchybiło w stosunku do terenu mającego znaczenie dla Wspólnoty „Alto Sil” zobowiązaniom ciążącym na nim na mocy art. 6 ust. 2 dyrektywy Rady 92/43.

4) W pozostałym zakresie skarga zostaje oddalona.

5) Królestwo Hiszpanii obok kosztów własnych pokrywa dwie trzecie kosztów poniesionych przez Komisję Europejską. Komisja Europejska pokrywa jedną trzecią swoich kosztów.

\section{III.3. WYROK TRYBUNAŁU (PIĄTA IZBA) Z DNIA 15 GRUDNIA 2011 R. W SPRAWIE C-560/08 KOMISJA EUROPEJSKA PRZECIWKO KRÓLESTWU HISZPANII ${ }^{22}$}

Przedmiot: uchybienie zobowiązaniom państwa członkowskiego - Naruszenie art. 2 ust. 1, art. 3, art. 4 ust. 1 albo ust. 2, art. 5, art. 6 ust. 2, art. 8 i art. 9 dyrektywy Rady 85/337/EWG z dnia 27 czerwca 1985 r. w sprawie oceny skutków wywieranych przez niektóre przedsięwzięcia publiczne i prywatne na środowisko naturalne (Dz. U. L 175, s. 40) oraz art. 6 ust. 3 i 4

22 Opubl.: http://curia.eu. 
w związku z art. 7 i art. 12 ust. 1 lit. b) i d) dyrektywy Rady 92/43/EWG z dnia 21 maja 1992 r. w sprawie ochrony siedlisk przyrodniczych oraz dzikiej fauny i flory (Dz. U. L 206, s. 7) w wykładni dokonanej przez Trybunał Sprawiedliwości w wyrokach z dnia 13 stycznia 2005 r. w sprawie C-117/03 oraz z dnia 14 września 2006 r. w sprawie C-244/05 - Plany rozbudowy lub modernizacji drogi M-501 - SOO [specjalny obszar ochrony] ES 0000056 „Encinares del río Alberche y río Cofio [lasy dębów korkowych nad rzekami Alberche i Cofio]" - Proponowany obszar o znaczeniu dla Wspólnoty (OZW) ES 3110005 „Cuenca del río Guadarrama [dorzecze rzeki Guadarrama]” oraz proponowany OZW ES 3110007 „Cuencas de los ríos Alberche y Cofio [dorzecza rzek Alberche i Cofio]"

Sentencja: 1) Nie spełniwszy wymogów określonych w: - art. 2 ust. 1, art. 3, art. 4 ust. 1 albo ust. 2, w zależności od przypadku, a także art. 5 dyrektywy Rady 85/337/EWG z dnia 27 czerwca 1985 r. w sprawie oceny skutków wywieranych przez niektóre przedsięwzięcia publiczne i prywatne na środowisko naturalne, zmienionej dyrektywą 2003/35/WE Parlamentu Europejskiego i Rady z dnia 26 maja 2003 r., w związku z realizacją odrębnych projektów rozbudowy lub modernizacji drogi M-501 na odcinkach 1, 2 i 4;

- art. 6 ust. 2 i art. 8 dyrektywy 85/337/EWG, zmienionej dyrektywą 2003/35, w odniesieniu do realizacji odrębnych projektów rozbudowy lub modernizacji odcinków 2 i 4 tej drogi;

- art. 9 dyrektywy 85/337, zmienionej dyrektywą 2003/35, w związku z realizacją odrębnych projektów rozbudowy lub modernizacji odcinków 1, 2 i 4 ww. drogi;

- art. 6 ust. 3 i 4 w związku z art. 7 dyrektywy Rady 92/43/EWG z dnia 21 maja 1992 r. w sprawie ochrony siedlisk przyrodniczych oraz dzikiej fauny i flory, w związku z realizacją odrębnych projektów rozbudowy lub modernizacji odcinków 1, 2 i 4 drogi M-501 w odniesieniu do specjalnego obszaru ochrony ptaków ES0000056 „Encinares del río Alberche y río 
Cofio [lasy dębów korkowych nad rzekami Alberche i Cofio]" oraz

- art. 12 ust. 1 lit. b) i d) dyrektywy 92/43 w związku $\mathrm{z}$ realizacją odrębnych projektów rozbudowy lub modernizacji odcinka 1 drogi M-501, w odniesieniu do proponowanego obszaru o znaczeniu dla Wspólnoty ES3110005 „Cuenca del río Guadarrama [dorzecze rzeki Guadarrama]" oraz odcinków 2 i 4 tej drogi, w odniesieniu do proponowanego obszaru o znaczeniu dla Wspólnoty ES3110007 „Cuencas de los ríos Alberche y Cofio [dorzecza rzek Alberche i Cofio]",

Królestwo Hiszpanii uchybiło zobowiązaniom, które na nim ciążą na mocy wyżej wymienionych przepisów.

2) Królestwo Hiszpanii zostaje obciążone kosztami postępowania.

3) Rzeczpospolita Polska pokrywa własne koszty.

\section{III.4. WYROK TRYBUNAŁU (SIÓDMA IZBA) Z DNIA 26 STYCZNIA 2012 R. W SPRAWIE C-192/11 KOMISJA EUROPEJSKA PRZECIWKO RZECZYPOSPOLITEJ POLSKIEJ ${ }^{23}$}

Przedmiot: uchybienie zobowiązaniom państwa członkowskiego - Naruszenie art. 1, art. 5 oraz art. 9 ust. 1 i 2 dyrektywy Parlamentu Europejskiego i Rady 2009/147/WE z dnia 30 listopada 2009 r. w sprawie ochrony dzikiego ptactwa (Dz. U. L 20, s. 7) - Zakres stosowania - Ograniczenie ochrony jedynie do gatunków ptaków występujących na terytorium krajowym Nieprawidłowe określenie warunków ustanowienia odstępstw od zakazów przewidzianych w dyrektywie

Sentencja: 1) Nie obejmując ochroną wszystkich gatunków dzikich ptaków występujących naturalnie w stanie dzikim na europejskim terytorium państw członkowskich, które ochroną obejmuje dyrektywa Parlamentu Europejskiego i Rady 2009/147/WE z dnia 30 listopada 2009 r. w sprawie ochrony dzikiego ptactwa, a także nieprawidłowo określa-

23 Opubl.: http://curia.eu. 
jąc warunki ustanowienia odstępstw od zakazów ustanowionych w tej dyrektywie, Rzeczpospolita Polska uchybiła zobowiązaniom ciążącym na niej na mocy art. 1, art. 5 oraz art. 9 ust. 1 i 2 tej dyrektywy.

2) Rzeczpospolita Polska zostaje obciążona kosztami postępowania.

III.5. WYROK TRYBUNAEU (CZWARTA IZBA) Z DNIA 15 MARCA 2012 R. W SPRAWIE C-340/10 KOMISJA EUROPEJSKA PRZECIWKO REPUBLICE

\section{CYPRYJSKIEJ ${ }^{24}$}

Przedmiot: uchybienie zobowiązaniom państwa członkowskiego - Naruszenie art. 4 ust. 1 i art. 12 ust. 1 dyrektywy Rady 92/43/EWG z dnia 21 maja 1992 r. w sprawie ochrony siedlisk przyrodniczych oraz dzikiej fauny i flory (Dz. U. L 206, s. 7) - Brak włączenia jeziora Paralimni do krajowego wykazu terenów, które mogą zostać uznane za tereny mające znaczenie dla Wspólnoty - Brak ustanowienia systemu ochrony gatunku natrix natrix cypriaca (cypryjskiego zaskrońca zwyczajnego)

Sentencja: 1) Republika Cypryjska

- poprzez brak włączenia terenu jeziora Paralimni do krajowego wykazu proponowanych terenów mających znaczenie dla Wspólnoty,

- poprzez zezwalanie na działalność, która poważnie zagraża cechom ekologicznym jeziora Paralimni, oraz poprzez brak przyjęcia środków ochronnych koniecznych dla zachowania populacji gatunku Natrix natrix cypriaca (cypryjskiego zaskrońca zwyczajnego), który ma znaczenie ekologiczne dla jeziora Paralimni i zapory Xyliatos, oraz

- poprzez brak przyjęcia środków koniecznych dla ustanowienia i stosowania systemu ścisłej ochrony tego gatunku,

- uchybiła zobowiązaniom ciążącym na niej, odpowiednio, na mocy art. 4 ust. 1 dyrektywy Rady

24 Opubl.: http://curia.eu. 
92/43/EWG z dnia 21 maja 1992 r. w sprawie ochrony siedlisk przyrodniczych oraz dzikiej fauny i flory, zmienionej dyrektywą Rady 2006/105/WE z dnia 20 listopada 2006 r., na mocy dyrektywy 92/43 ze zmianami, a także na mocy art. 12 ust. 1 tejże dyrektywy 92/43 ze zmianami.

2) Republika Cypryjska zostaje obciążona kosztami postępowania.

\section{III.6. WYROK TRYBUNAŁU (ÓSMA IZBA) Z DNIA 15 MARCA \\ 2012 R. W SPRAWIE C-46/11 KOMISJA EUROPEJSKA PRZECIWKO RZECZYPOSPOLITEJ POLSKIEJ ${ }^{25}$}

Przedmiot: uchybienie zobowiązaniom państwa członkowskiego - Naruszenie art. 16 ust. 1 dyrektywy Rady 92/43/EWG z dnia 21 maja 1992 r. w sprawie ochrony siedlisk przyrodniczych oraz dzikiej fauny i flory (Dz. U. L 206, s. 7) - Niewystarczająca ochrona niektórych gatunków, w szczególności wydry (Lutra Lutra)

Sentencja: 1) Nie dokonując prawidłowo transpozycji warunków wprowadzania odstępstw przewidzianych $\mathrm{w}$ art. 16 ust. 1 dyrektywy Rady 92/43/EWG z dnia 21 maja 1992 r. w sprawie ochrony siedlisk przyrodniczych oraz dzikiej fauny i flory, Rzeczpospolita Polska uchybiła zobowiązaniom, które na niej ciążą na mocy owego przepisu.

2) Rzeczpospolita Polska zostaje obciążona kosztami postępowania.

25 Opubl.: http://curia.eu. 


\title{
IV. OCHRONA KLIMATU
}

\author{
IV.1. WYROK TRYBUNAŁU (WIELKA IZBA) Z DNIA 21 GRUDNIA 2011 R. \\ W SPRAWIE C-366/10 THE AIR TRANSPORT ASSOCIATION \\ OF AMERICA, AMERICAN AIRLINES, INC., CONTINENTAL AIRLINES, \\ INC., UNITED AIRLINES, INC. PRZECIWKO THE SECRETARY OF STATE \\ FOR ENERGY AND CLIMATE CHANGE ${ }^{26}$
}

Przedmiot: wniosek o wydanie orzeczenia w trybie prejudycjalnym - High Court of Justice Queen's Bench Division (Administrative Court) - Ważność dyrektywy 2008/101/WE Parlamentu Europejskiego i Rady z dnia 19 listopada 2008 r. zmieniającej dyrektywę 2003/87/WE w celu uwzględnienia działalności lotniczej w systemie handlu przydziałami [uprawnieniami do] emisji gazów cieplarnianych we Wspólnocie (Dz. U. 2009, L 8, s. 3) - Możliwość powołania się na pewne reguły lub postanowienia prawa międzynarodowego

Sentencja: 1) W takich okolicznościach jak okoliczności sprawy przed sądem krajowym spośród zasad i norm prawa międzynarodowego wymienionych przez sąd krajowy w celu dokonania oceny ważności dyrektywy 2008/101/WE Parlamentu Europejskiego i Rady z dnia 19 listopada 2008 r. zmieniającej dyrektywę 2003/87/WE w celu uwzględnienia działalności lotniczej $\mathrm{w}$ systemie handlu przydziałami [uprawnieniami do] emisji gazów cieplarnianych we Wspólnocie można się powołać jedynie na:

- z jednej strony, w granicach kontroli oczywistego błędu, który może zostać przypisany Unii, w ocenie jej kompetencji do wydania tej dyrektywy w świetle tych zasad:

- zasadę, zgodnie z którą każde państwo posiada całkowitą i wyłączną suwerenność w przestrzeni powietrznej nad swoim terytorium,

26 Opubl.: http://curia.eu. 
- zasadę, zgodnie z którą żadne państwo nie może prawnie próbować poddać jakiejkolwiek części morza pełnego swej suwerenności,

- zasadę, która gwarantuje wolność przelotu nad morzem pełnym,

- z drugiej strony,

- art. 7 i art. 11 ust. 1 i 2 lit. c) umowy o transporcie lotniczym zawartej w dniach 25 i 30 kwietnia 2007 r. między Stanami Zjednoczonymi Ameryki z jednej strony a Wspólnotą Europejską i jej państwami członkowskimi z drugiej strony, zmienionej protokołem, oraz

- art. 15 ust. 3 tej umowy w związku z art. 2 i art. 3 ust. 4 tejże umowy.

2) Analiza dyrektywy 2008/101 nie wykazała istnienia okoliczności, które wpływałyby na jej ważność.

\section{IV.2. WYROK SĄDU Z DNIA 1 LUTEGO 2012 R. W SPRAWIE T-237/09 RÉGION WALLONNE PRZECIWKO KOMISJI ${ }^{27}$}

Przedmiot: żądanie stwierdzenia nieważności części decyzji Komisji z dnia 27 marca 2009 r. dotyczącej krajowego planu rozdziału uprawnień do emisji gazów cieplarnianych notyfikowanego przez Królestwo Belgii na okres obejmujący lata 2008-2012, udzielającej centralnemu administratorowi polecenia wprowadzenia do niezależnego dziennika transakcji Wspólnoty korekty w belgijskiej tabeli krajowego planu rozdziału uprawnień.

Sentencja: 1) Stwierdza się nieważność decyzji Komisji z dnia 27 marca 2009 r. udzielającej centralnemu administratorowi polecenia wprowadzenia do niezależnego dziennika transakcji Wspólnoty korekty w belgijskiej tabeli krajowego planu rozdziału uprawnień, $w$ zakresie $\mathrm{w}$ jakim zawiera ona odmowę polecenia temu administratorowi, by

\footnotetext{
27 Opubl.: http://curia.eu.
} 
wprowadził korektę przydziału uprawnień na rzecz instalacji nr 116 oznaczonej jako „Arcelor-Cockerill Sambre_HF6 Seraing", o którą Królestwo Belgii wniosło w piśmie z dnia 18 lutego 2009 r.

2) Komisja Europejska zostaje obciążona kosztami postępowania.

\section{IV.3. WYROK TRYBUNAŁU (DRUGA IZBA) Z DNIA 29 MARCA 2012 R. W SPRAWIE C-504/09 P KOMISJA EUROPEJSKA PRZECIWKO RZECZPOSPOLITEJ POLSKIEJ, WĘGROM, REPUBLICE LITEWSKIEJ, REPUBLICE SŁOWACKIEJ ORAZ ZJEDNOCZONEMU KRÓLESTWU WIELKIEJ BRYTANII I IRLANDII PÓŁNOCNEJ ${ }^{28}$}

Przedmiot: odwołanie od wyroku Sądu Pierwszej Instancji (druga izba) z dnia 23 września 2009 r. w sprawie T-183/07 Polska przeciwko Komisji, którym Sąd stwierdził nieważność decyzji Komisji C(2007) 1295 wersja ostateczna z dnia 26 marca 2007 r. dotyczącej krajowego planu rozdziału uprawnień do emisji gazów cieplarnianych zgłoszonego przez Polskę na lata 2008-2012 zgodnie z dyrektywą 2003/87/WE Parlamentu Europejskiego i Rady z dnia 13 października 2003 r. ustanawiającą system handlu przydziałami emisji gazów cieplarnianych we Wspólnocie oraz zmieniającą dyrektywę Rady 96/61/WE (Dz. U. L 275, s. 32) - Zasada ne ultra petita - Granice kontroli sądowej - Naruszenie art. 48 ust. 2 regulaminu Sądu - Błędna wykładnia art. 296 TFUE, art. 9 ust. 3 dyrektywy 2003/87/WE, a także art. 1 ust. 1, art. 2 ust. 1 oraz art. 3 ust. 1 decyzji Komisji C (2007)1295 wersja ostateczna

Sentencja:

1) Odwołanie zostaje oddalone.

2) Komisja Europejska zostaje obciążona kosztami postępowania.

3) Republika Czeska, Królestwo Danii, Rumunia, a także Zjednoczone Królestwo Wielkiej Brytanii i Irlandii Północnej pokrywają własne koszty.

28 Opubl.: http://curia.eu. 


\section{IV.4. WYROK TRYBUNAŁU (DRUGA IZBA) Z DNIA 29 MARCA 2012 R. W SPRAWIE C-505/09 P KOMISJA EUROPEJSKA PRZECIWKO REPUBLICE ESTOŃSKIEJ, REPUBLICE LITEWSKIEJ, REPUBLICE SŁOWACKIEJ ORAZ ZJEDNOCZONEMU KRÓLESTWU WIELKIEJ BRYTANII I IRLANDII PÓŁNOCNEJ ${ }^{29}$}

Przedmiot: odwołanie od wyroku Sądu Pierwszej Instancji (siódma izba) z dnia 23 września 2009 r. w sprawie T-263/07 Estonia przeciwko Komisji, którym Sąd stwierdził nieważność decyzji Komisji z dnia 4 maja 2007 r. dotyczącej krajowego planu rozdziału uprawnień do emisji gazów cieplarnianych zgłoszonego przez Republikę Estońską na lata 2008-2012 zgodnie z dyrektywą 2003/87/WE Parlamentu Europejskiego i Rady z dnia 13 października 2003 r. ustanawiającą system handlu przydziałami emisji gazów cieplarnianych we Wspólnocie oraz zmieniającą dyrektywę Rady 96/61/WE (Dz. U. L 275, s. 32) - Naruszenie prawa przy badaniu dopuszczalności skargi o stwierdzenie nieważności - Błędna wykładnia art. 9 ust. 1 i 3 oraz art. 11 ust. 2 dyrektywy 2003/87/WE oraz ogólnej zasady równego traktowania - Błędna interpretacja zakresu zastosowania zasady dobrej administracji - Błędna kwalifikacja przepisów zaskarżonej decyzji jako nierozerwalnie związanych, co doprowadziło do stwierdzenia nieważności całej decyzji, zamiast jej części.

Sentencja:

1) Odwołanie zostaje oddalone.

2) Komisja Europejska zostaje obciążona kosztami postępowania.

3) Republika Czeska, Królestwo Danii i Republika Łotewska pokrywają własne koszty.

29 Opubl.: http://curia.eu. 


\title{
V. PARTYCYPACJA SPOŁECZEŃSTWA W OCHRONIE ŚRODOWISKA
}

\author{
V.1. WYROK TRYBUNAŁU (WIELKA IZBA) Z DNIA 18 PAŹDZIERNIKA \\ 2011 R. W SPRAWACH POŁĄCZONYCH OD C-128/09 D0 C-131/09, \\ C-134/09 I C-135/09 ANTOINE BOXUS, WILLY ROUA (C-128/09), \\ GUIDO DURLET I IN. (C-129/09), PAUL FASTREZ, HENRIETTE \\ FASTREZ (C-130/09), PHILIPPE DARAS (C-131/09), ASSOCIATION DES \\ RIVERAINS ET HABITANTS DES COMMUNES PROCHES DE L'AÉROPORT \\ BSCA (BRUSSELS SOUTH CHARLEROI AIRPORT) (ARACH) (C-134/09 \\ IC-135/09), BERNARD PAGE (C-134/09), LÉON L'HOIR, NADINE \\ DARTOIS (C-135/09) PRZECIWKO RÉGION WALLONNE ${ }^{30}$
}

Przedmiot: Wniosek o wydanie orzeczenia w trybie prejudycjalnym - Conseil d'État (Belgia) - Wykładnia art. 1, 5-8 i 10a dyrektywy Rady 85/337/EWG z dnia 27 czerwca 1985 r. w sprawie oceny skutków wywieranych przez niektóre przedsięwzięcia publiczne i prywatne na środowisko naturalne (Dz. U. L 175, s. 40), zmienionej dyrektywą Rady 97/11/WE z dnia 3 marca 1997 r. (Dz. U. L s. 5) i dyrektywą 2003/35/WE Parlamentu Europejskiego i Rady z dnia 26 maja 2003 r. przewidującą udział społeczeństwa w odniesieniu do sporządzania niektórych planów i programów w zakresie środowiska oraz zmieniającą w odniesieniu do udziału społeczeństwa i dostępu do wymiaru sprawiedliwości dyrektywy Rady 85/337/EWG i 96/61/WE (Dz. U. L 156, s. 17) - Wykładnia art. 6 i 9 Konwencji z Aarhus o dostępie do informacji, udziale społeczeństwa w podejmowaniu decyzji oraz dostępie do wymiaru sprawiedliwości w sprawach dotyczących środowiska, zawartej w dniu 25 czerwca 1998 r. i zatwierdzonej w imieniu Wspólnoty Europejskiej decyzją Rady 2005/370/WE z dnia 17 lutego 2005 r. (Dz. U. L 124, s. 1) - Uznanie za szczególne akty ustawodawstwa krajowego 
niektórych pozwoleń „ratyfikowanych” dekretem, których wydanie uwzględnione jest nadrzędnymi względami interesu ogólnego? - Brak pełnego prawa do wniesienia środka prawnego przeciwko decyzji $\mathrm{w}$ sprawie zezwolenia na przedsięwzięcia mogące znacząco oddziaływać na środowisko - Fakultatywny lub obowiązkowy charakter istnienia takiego prawa - Roboty związane z budową infrastruktury $\mathrm{z}$ wydłużeniem pasa startowego na lotnisku Liège-Bierset

Sentencja: 1) Artykuł 1 ust. 5 dyrektywy Rady 85/337/ EWG z dnia 27 czerwca 1985 r. w sprawie oceny skutków wywieranych przez niektóre przedsięwzięcia publiczne i prywatne na środowisko naturalne, zmienionej dyrektywą 2003/35/WE Parlamentu Europejskiego i Rady z dnia 26 maja 2003 r., należy interpretować $\mathrm{w}$ ten sposób, że z zakresu jej zastosowania są wyłączone jedynie przedsięwzięcia szczegółowo przyjęte przez szczególny akt ustawodawczy, w taki sposób, aby cele tej dyrektywy były osiągnięte w procesie ustawodawczym. Sąd krajowy powinien zbadać, czy te dwa warunki zostały spełnione, uwzględniając zarówno treść przyjętego aktu ustawodawczego, jak i cały proces ustawodawczy, który doprowadził do jego wydania, a w szczególności akty przygotowawcze i debaty parlamentarne. W tym względzie aktu ustawodawczego, który tylko po prostu „zatwierdzałby” istniejący akt administracyjny, ograniczając się do powołania się na nadrzędne względy interesu ogólnego, bez uprzedniego rozpoczęcia procesu ustawodawczego co do istoty, który umożliwiałby spełnienie tych warunków, nie można uznać za szczególny akt ustawodawczy $w$ rozumieniu tego przepisu; nie jest więc on wystarczający, aby wykluczyć przedsięwzięcie z zakresu dyrektywy 85/337, zmienionej dyrektywą 2003/35.

2) Artykuł 9 ust. 2 Konwencji o dostępie do informacji, udziale społeczeństwa $\mathbf{w}$ podejmowaniu decyzji oraz dostępie do wymiaru sprawiedliwości w sprawach dotyczących środowiska zawartej w dniu 25 czerwca 1998 r. i zatwierdzonej w imieniu Wspólnoty Europejskiej decyzją Rady 2005/370/WE z dnia 17 lutego 2005 r. i art. 10a dyrektywy 
85/337, zmienionej dyrektywą 2003/35, należy interpretować w ten sposób, że:

- gdy przedsięwzięcie, które objęte jest zakresem zastosowania tych przepisów, zatwierdzono $\mathrm{w}$ drodze aktu ustawodawczego, powinna istnieć możliwość skierowania zgodnie z krajowymi zasadami proceduralnymi do sądu lub niezależnego i bezstronnego organu powołanego z mocy ustawy kwestii, czy ten akt ustawodawczy spełnia wymogi określone $\mathrm{w}$ art. 1 ust. 5 tej dyrektywy;

- w przypadku gdy nie istnieje możliwość wniesienia skargi na ten akt o charakterze i zakresie, jakie wskazano powyżej, każdy sąd krajowy orzekający w ramach swej właściwości winien przeprowadzić kontrolę opisaną w powyższym punkcie i ewentualnie wyciągnąć z niej konsekwencje, odstępując od stosowania tego aktu ustawodawczego.

\section{V.2. WYROK TRYBUNAEU (WIELKA IZBA) Z DNIA 14 LUTEGO 2012 R. W SPRAWIE C-204/09 FLACHGLAS TORGAU GMBH PRZECIWKO BUNDESREPUBLLIK DEUTSCHLAND ${ }^{31}$}

Przedmiot: wniosek o wydanie orzeczenia w trybie prejudycjalnym - Bundesverwaltungsgericht - Wykładnia art. 2 ust. 2 zdanie drugie i art. 4 ust. 2 zdanie pierwsze lit. a) dyrektywy 2003/4/WE Parlamentu Europejskiego i Rady z dnia 28 stycznia 2003 r. w sprawie publicznego dostępu do informacji dotyczących środowiska i uchylającej dyrektywę Rady 90/313/EWG (Dz. U. L 41, s. 26) - Uregulowanie krajowe zwalniające z obowiązku udostępnienia informacji najwyższe władze związkowe w zakresie, w jakim współdziałają w procesie legislacyjnym, i przewidujące ogólnie, że wniosek o udostępnienie informacji można odrzucić, jeżeli ich udostępnienie narusza poufność obrad - Ograniczenia uprawnienia państw członkowskich do wyłączenia z pojęcia „organ władzy publicznej” przewidzianego

31 Opubl.: http://curia.eu. 
w dyrektywie 2003/4/WE organy pełniące funkcje o charakterze ustawodawczym - Warunki zastosowania odstępstwa związanego z poufnością obrad

Sentencja: 1) Artykuł 2 pkt 2 akapit drugi zdanie pierwsze dyrektywy 2003/4/WE Parlamentu Europejskiego i Rady z dnia 28 stycznia 2003 r. w sprawie publicznego dostępu do informacji dotyczących środowiska i uchylającej dyrektywę Rady 90/313/EWG należy interpretować w ten sposób, że przyznana $\mathrm{w}$ tym przepisie państwom członkowskim możliwość, by nie traktować jako organów władzy publicznej „organów lub instytucji pełniących funkcje o charakterze [...] ustawodawczym", może mieć zastosowanie do ministerstw $\mathrm{w}$ zakresie, $\mathrm{w}$ jakim uczestniczą one $\mathrm{w}$ procesie legislacyjnym, w szczególności poprzez przedkładanie projektów ustaw i opinii, i że możliwość ta nie jest uzależniona od spełnienia warunków określonych $\mathrm{w}$ art. 2 pkt 2 akapit drugi zdanie drugie tej dyrektywy.

2) Artykuł 2 pkt 2 akapit drugi zdanie pierwsze dyrektywy 2003/4 należy interpretować w ten sposób, że z przyznanej $w$ tym przepisie państwom członkowskim możliwości, by nie traktować jako organów władzy publicznej organów lub instytucji pełniących funkcje o charakterze ustawodawczym, nie można już skorzystać, jeżeli dany proces legislacyjny został zakończony.

3) Artykuł 4 ust. 2 akapit pierwszy lit. a) dyrektywy 2003/4 należy interpretować w ten sposób, że ustanowiony w nim warunek, by poufność obrad organów władzy publicznej była przewidziana prawnie, można uznać za spełniony, w przypadku gdy w prawie krajowym danego państwa członkowskiego istnieje przepis przewidujący w sposób ogólny, że poufność obrad organów władzy publicznej stanowi powód odmowy dostępu do informacji o środowisku, które znajdują się $\mathrm{w}$ posiadaniu tych organów, o ile prawo krajowe jasno określa pojęcie obrad, co powinien zweryfikować sąd krajowy. 


\section{V.3. WYROK TRYBUNAŁU (CZWARTA IZBA) Z DNIA 16 LUTEGO 2012 R. W SPRAWIE C-182/10 MARIE-NOËLLE SOLVAY I IN. PRZECIWKO RÉGION WALLONNE ${ }^{32}$}

Przedmiot: wniosek o wydanie orzeczenia w trybie prejudycjalnym - Cour constitutionnelle (dawniej Cour d'arbitrage) - Wykładnia art. 2 (pkt 2), 3 (ust. 9), 6 (ust. 9) i 9 (ust. 2, 3 i 4) Konwencji z Aarhus o dostępie do informacji, udziale społeczeństwa w podejmowaniu decyzji oraz dostępie do [wymiaru] sprawiedliwości w sprawach dotyczących środowiska, zawartej w dniu 25 czerwca 1998 r. i zatwierdzonej w imieniu Wspólnoty Europejskiej decyzją Rady 2005/370/WE z dnia 17 lutego 2005 r. (Dz. U. L 124, s. 1) - Wykładnia art. 1 (ust. 5), 9 (ust. 1) i 10a dyrektywy Rady 85/337/EWG z dnia 27 czerwca 1985 r. w sprawie oceny skutków wywieranych przez niektóre przedsięwzięcia publiczne i prywatne na środowisko naturalne (Dz. U. L 175, s. 40) - Wykładnia art. 6 ust. 3 i 4 dyrektywy Rady 92/43/ EWG z dnia 21 maja 1992 r. w sprawie ochrony siedlisk przyrodniczych oraz dzikiej fauny i flory (Dz. U. L 206, s. 7) - Pojęcie „władzy publicznej” - Moc i zakres uściśleń zawartych w wytycznych na temat stosowania konwencji z Aarhus - Wyłączenie z zakresu stosowania konwencji aktów ustawodawczych, takich jak pozwolenia na budowę czy pozwolenia środowiskowe wydawane na podstawie dekretu przez ustawodawcę regionalnego - Zgodność postępowania prowadzącego do wydania pozwoleń podlegających zaskarżeniu wyłącznie przed Cour constitutionnelle i sądami cywilnymi z konwencją i prawem wspólnotowym - Zezwolenie na przedsięwzięcie w braku właściwej oceny jego skutków na środowisko

Sentencja: 1) Chociaż przy dokonywaniu wykładni art. 2 ust. 2 i art. 9 ust. 4 konwencji o dostępie do informacji, udziale społeczeństwa w podejmowaniu decyzji oraz dostępie do [wymiaru] sprawiedliwości w sprawach dotyczących środowiska, zawartej w dniu 25 czerwca 1998 r. i zatwierdzonej w imieniu Wspólnoty Europejskiej decyzją

32 Opubl.: http://curia.eu. 
Rady 2005/370/WE z dnia 17 lutego 2005 r., można brać pod uwage wytyczne na temat stosowania tej konwencji, to jednak nie mają one żadnej mocy wiążącej i nie posiadają znaczenia normatywnego, jakie nadano postanowieniom rzeczonej konwencji.

2) Artykuł 2 ust. 2 konwencji o dostępie do informacji, udziale społeczeństwa $\mathrm{w}$ podejmowaniu decyzji oraz dostępie do [wymiaru] sprawiedliwości w sprawach dotyczących środowiska i art. 1 ust. 5 dyrektywy Rady 85/337/EWG z dnia 27 czerwca 1985 r. w sprawie oceny skutków wywieranych przez niektóre przedsięwzięcia publiczne i prywatne na środowisko naturalne, zmienionej dyrektywą 2003/35/WE Parlamentu Europejskiego i Rady z dnia 26 maja 2003 r., należy interpretować $\mathrm{w}$ ten sposób, że z zakresów zastosowania tych aktów prawnych są wyłączone jedynie przedsięwzięcia szczegółowo przyjęte przez szczególny akt ustawodawczy, w taki sposób, aby cele rzeczonych aktów prawnych były osiągnięte $w$ procesie ustawodawczym. Zadaniem sądu krajowego jest upewnienie się, że obydwa te warunki zostały spełnione, przy uwzględnieniu zarówno treści przyjętego aktu ustawodawczego, jak i całego procesu ustawodawczego, który doprowadził do jego przyjęcia, w szczególności zaś aktów przygotowawczych i debat parlamentarnych. W tym względzie aktu ustawodawczego, który tylko po prostu „zatwierdzałby" istniejący akt administracyjny, ograniczając się do powołania się na nadrzędne względy interesu ogólnego, bez uprzedniego rozpoczęcia procesu ustawodawczego co do istoty, który umożliwiałby spełnienie tych warunków, nie można uznać za szczególny akt ustawodawczy w rozumieniu tego przepisu, wobec czego nie jest on wystarczający, aby wykluczyć przedsięwzięcie z zakresów zastosowania wskazanej konwencji i dyrektywy, ze zmianami.

3) Artykuł 3 ust. 9 i art. 9 ust. 2-4 konwencji o dostępie do informacji, udziale społeczeństwa w podejmowaniu decyzji oraz dostępie do [wymiaru] sprawiedliwości w sprawach dotyczących środowiska oraz art. 10a dyrektywy 85/337, zmienionej dyrektywą 2003/35, należy interpretować $\mathrm{w}$ ten sposób, że: 
- gdy przedsięwzięcie, które objęte jest zakresem zastosowania tych przepisów, zatwierdzono w drodze aktu ustawodawczego, powinna istnieć możliwość skierowania zgodnie z krajowymi zasadami proceduralnymi do sądu lub niezależnego i bezstronnego organu powołanego z mocy ustawy kwestii, czy ten akt ustawodawczy spełnia wymogi określone $\mathrm{w}$ art. 1 ust. 5 tej dyrektywy, ze zmianami, oraz

- w przypadku gdy nie istnieje możliwość wniesienia skargi na taki akt o charakterze i zakresie, jakie wskazano powyżej, każdy sąd krajowy orzekający w ramach swej właściwości winien przeprowadzić kontrolę opisaną $w$ powyższym tiret $i$ ewentualnie wyciągnąć z niej konsekwencje, odstępując od stosowania tego aktu ustawodawczego.

4) Artykuł 6 ust. 9 konwencji o dostępie do informacji, udziale społeczeństwa $\mathrm{w}$ podejmowaniu decyzji oraz dostępie do [wymiaru] sprawiedliwości w sprawach dotyczących środowiska i art. 9 ust. 1 dyrektywy 85/337, zmienionej dyrektywą 2003/35, należy interpretować w ten sposób, że nie wymagają one, aby w samej decyzji wskazane były powody, dla których właściwe władze uznały, że jest ona konieczna. Jednakże na żądanie zainteresowanej osoby właściwe władze administracyjne mają obowiązek przekazać jej uzasadnienie podjęcia takiej decyzji lub właściwe informacje i dokumenty.

5) Artykuł 6 ust. 3 dyrektywy Rady 92/43/EWG z dnia 21 maja 1992 r. w sprawie ochrony siedlisk przyrodniczych oraz dzikiej fauny i flory należy interpretować $\mathbf{w}$ ten sposób, że nie zezwala on władzom krajowym, w tym władzom ustawodawczym, na zatwierdzenie planu lub przedsięwzięcia bez upewnienia się, że taki plan lub przedsięwzięcie nie naruszy integralności danego terenu.

6) Artykuł 6 ust. 4 dyrektywy 92/43 należy interpretować w ten sposób, że budowy infrastruktury mającej posłużyć do utworzenia centrum administracyjnego nie można co do zasady uznać za nadrzędny wzgląd interesu publicznego, 4/2012 w tym wzgląd o charakterze społecznym lub gospodarczym 
w rozumieniu tego przepisu, mogący uzasadniać realizację planu lub przedsięwzięcia naruszającego integralność danego terenu.

\section{POZOSTAŁE}

\section{VI.1. POWAŻNE AWARIE - WYROK TRYBUNAŁU (PIERWSZA IZBA) Z DNIA 15 WRZEŚNIA 2011 R. W SPRAWIE C-53/10 LAND HESSEN PRZECIWKO FRANZ MÜCKSCH OHG ${ }^{33}$}

Przedmiot: wniosek o wydanie orzeczenia w trybie prejudycjalnym - Bundesverwaltungsgericht - Wykładnia art. 12 ust. 1 dyrektywy Rady 96/82/WE z dnia 9 grudnia 1996 r. w sprawie kontroli niebezpieczeństwa poważnych awarii związanych z substancjami niebezpiecznymi (Dz. U. 1997, L 10, s. 13), zmienionej rozporządzeniem Parlamentu Europejskiego i Rady (WE) nr 1137/2008 z dnia 22 października 2008 r. dostosowującym do decyzji Rady 1999/468/WE niektóre akty podlegające procedurze ustanowionej w art. 251 traktatu, w zakresie procedury regulacyjnej połączonej z kontrolą dyrektywą (Dz. U. L 311, s. 1) - Zapobieganie poważnym awariom - Zakres obowiązku zapewnienia przez państwa członkowskie, by ich polityka zagospodarowania przestrzennego uwzględniała, w dłuższej perspektywie, potrzebę utrzymania właściwych odległości pomiędzy obszarami użytku publicznego a zakładami, w których znajdują się duże ilości substancji niebezpiecznych - Budowa centrum ogrodniczego w pobliżu takiego zakładu - Istnienie wielu innych placówek handlowych w tej samej strefie ryzyka.

Sentencja: 1) Artykuł 12 ust. 1 dyrektywy Rady 96/82/WE z dnia 9 grudnia 1996 r. w sprawie kontroli niebezpieczeństwa poważnych awarii związanych z substancjami niebezpiecznymi, zmienionej dyrektywą 2003/105/WE Parlamentu Europejskiego i Rady z dnia 16 grudnia 2003 r., należy in-

33 Opubl.: http://curia.eu. 
terpretować w ten sposób, że obowiązek zapewnienia przez państwa członkowskie, iż uwzględniona zostanie potrzeba utrzymania, w dłuższej perspektywie, właściwych odległości między zakładami objętymi tą dyrektywą, a obiektami użytku publicznego, ciąży również na organie publicznym takim jak miasto Darmstadt, które jest właściwe do wydawania pozwoleń na budowę, nawet jeżeli wykonuje ono to uprawnienie $\mathrm{w}$ drodze decyzji związanej.

2) Przewidziany $w$ art. 12 ust. 1 dyrektywy 96/82, zmienionej dyrektywą 2003/105, obowiązek uwzględnienia potrzeby, w dłuższej perspektywie, utrzymania właściwych odległości między zakładami objętymi tą dyrektywą a budynkami użytku publicznego nie wymaga od właściwych organów krajowych, by zakazały lokalizacji budynku użytku publicznego $\mathrm{w}$ okolicznościach takich jak w sprawie przed sądem krajowym. Obowiązek ten stoi natomiast na przeszkodzie przepisom krajowym, które przewidują, że należy bezwzględnie wydać pozwolenie na lokalizację takiego budynku bez przeprowadzenia na etapie planowania przestrzennego lub na etapie decyzji indywidualnej należytej oceny ryzyka związanego z lokalizacją w obrębie obwodu wyznaczonego właściwymi odległościami.

\section{VI.2. ZINTEGROWANE ZAPOBIEGANIE ZANIECZYSZCZENIOM I ICH KONTROLA - WYROK TRYBUNAŁU (ÓSMA IZBA) Z DNIA 15 GRUDNIA 2011 R. W SPRAWIE C-585/10 NIELS MØLLER PRZECIWKO HADERSLEV KOMMUNE ${ }^{34}$}

Przedmiot: Wniosek o wydanie orzeczenia w trybie prejudycjalnym - Vestre Landsret - Wykładnia pkt 6.6 załącznika I do dyrektywy Rady 96/61/WE z dnia 24 września 1996 r. dotyczącej zintegrowanego zapobiegania zanieczyszczeniom i ich kontroli (Dz. U. L 257, s. 26) - Instalacje do intensywnej ho- 
dowli drobiu i świń, wyposażone w więcej niż 750 stanowisk dla macior - Kwestia włączenia do tej liczby miejsc dla loszek (samic świń po osiągnięciu dojrzałości płciowej, które się jeszcze nie oprosiły)

Sentencja: Wyrażenie „miejsca dla macior” znajdujące się w pkt 6.6 lit. c) załącznika I do dyrektywy Rady 96/61/WE z dnia 24 września 1996 r. dotyczącej zintegrowanego zapobiegania zanieczyszczeniom i ich kontroli, zmienionej rozporządzeniem (WE) nr 166/2006 Parlamentu Europejskiego i Rady z dnia 18 stycznia 2006 r., należy interpretować w ten sposób, że obejmuje ono miejsca dla loszek (samic świń już pokrytych, lecz jeszcze przed oproszeniem).

\section{VI.3. BIOPALIWA - WYROK TRYBUNALU (ÓSMA IZBA) \\ Z DNIA 21 GRUDNIA 2011 R. W SPRAWIE C-503/10 EWROETIE AD PRZECIWKO DIREKTOR NA AGENCIJA „MITNICI”35}

Przedmiot: Wniosek o wydanie orzeczenia w trybie prejudycjalnym - Wyrchowen administratiwen syd - Wykładnia art. 2 ust. 2 lit. a) dyrektywy 2003/30/WE Parlamentu Europejskiego i Rady z dnia 8 maja 2003 r. w sprawie wspierania użycia $\mathrm{w}$ transporcie biopaliw lub innych paliw odnawialnych (Dz. U. L 123, s. 42) i załącznika I do rozporządzenia Rady (EWG) nr 2658/87 z dnia 23 lipca 1987 r. w sprawie nomenklatury taryfowej i statystycznej oraz w sprawie Wspólnej taryfy celnej (Dz. U. L 256, s. 1) w brzmieniu zmienionym rozporządzeniem Komisji (EWG) nr 2587/91 z dnia 26 lipca 1991 r. (Dz. U. L 259, s. 1) - Wykładnia art. 2 ust. 1 dyrektywy Rady 2003/96/ WE z dnia 27 października 2003 r. w sprawie restrukturyzacji wspólnotowych przepisów ramowych dotyczących opodatkowania produktów energetycznych i energii elektrycznej (Dz. U. L 283, s. 51) i art. 20 ust. 1 tiret pierwsze dyrektywy Rady 92/83/EWG z dnia 19 października 1992 r. w sprawie harmonizacji struktury podatków akcyzowych od alkoholu i napojów alkoholowych (Dz. U. L 316, s. 21) - Wyrób uzyskany z bioma-

35 Opubl.: http://curia.eu. 
sy, zawierający estry, alkohole wyższe i aldehydy, o zawartości alkoholu wyższej niż $98 \%$, nieskażony - Pojęcie bioetanolu - Zaklasyfikowanie do podpozycji 22072000 (alkohol etylowy i pozostałe wyroby alkoholowe, o dowolnej mocy, skażone) albo do podpozycji 22071000 (alkohol etylowy nieskażony o objętościowej mocy alkoholu 80 \% obj. lub większej) w celu poboru podatku akcyzowego

Sentencja: 1) Definicję bioetanolu zawartą w art. 2 ust. 2 lit. a) dyrektywy 2003/30/WE Parlamentu Europejskiego i Rady z dnia 8 maja 2003 r. w sprawie wspierania użycia w transporcie biopaliw lub innych paliw odnawialnych należy interpretować $w$ ten sposób, że obejmuje ona taki wyrób, jak będący przedmiotem sporu przed sądem krajowym, który uzyskuje się w szczególności z biomasy i który zawiera ponad 98,5\% alkoholu etylowego, pod warunkiem że jest on sprzedawany jako biopaliwo do użycia w transporcie.

2) Prawo Unii należy interpretować $w$ ten sposób, że wyrób, taki jak będący przedmiotem sporu przed sądem krajowym, który zawiera ponad 98,5\% alkoholu etylowego i który nie został skażony z zastosowaniem wyraźnie przewidzianej procedury skażenia, objęty jest podatkiem akcyzowym, o którym mowa w art. 19 ust. 1 dyrektywy Rady 92/83/EWG z dnia 19 października 1992 r. w sprawie harmonizacji struktury podatków akcyzowych od alkoholu i napojów alkoholowych, nawet jeśli jest on uzyskiwany z biomasy według technologii odmiennej od tej, jakiej używa się do celów wyrobu alkoholu etylowego pochodzenia rolniczego, zawiera substancje czyniące go niezdatnym do spożycia przez człowieka, spełnia wymogi określone w projekcie normy europejskiej pr EN 15376 w odniesieniu do bioetanolu wykorzystywanego jako paliwo i ewentualnie odpowiada definicji bioetanolu określonej w art. 2 ust. 2 lit. a) dyrektywy $2003 / 30$. 


\section{VI.4. ORGANIZMY GENETYCZNIE MODYFIKOWANE - WYROK TRYBUNAŁU (CZWARTA IZBA) Z DNIA 6 WRZEŚNIA 2012 R. \\ W SPRAWIE C-36/11 PIONEER HI BRED ITALIA SRL PRZECIWKO MINISTERO DELLE POLITICHE AGRICOLE, ALIMENTARI E FORESTALI ${ }^{36}$}

Przedmiot: Wniosek o wydanie orzeczenia w trybie prejudycjalnym - Consiglio di Stato - Sezione Seconda - Wykładnia art. 16, 19, 22 i 26a dyrektywy Parlamentu Europejskiego i Rady 2001/18/WE z dnia 12 marca 2001 r. w sprawie zamierzonego uwalniania do środowiska organizmów zmodyfikowanych genetycznie i uchylającej dyrektywę Rady 90/220/EWG (Dz. U. L 106, s. 1) - Wykładnia art. 19 dyrektywy Rady 2002/53/WE z dnia 13 czerwca 2002 r. w sprawie Wspólnego katalogu odmian gatunków roślin rolniczych (Dz. U. L 193, s. 1) - Wniosek o zezwolenie na uprawy GMO wpisanych do wspólnego europejskiego katalogu odmian - Odrzucenie przez właściwy organ ze względu na brak krajowych przepisów w danej dziedzinie.

Sentencja: Uprawa organizmów genetycznie zmodyfikowanych takich jak odmiany kukurydzy MON 810 nie może podlegać krajowej procedurze wydawania zezwolenia, jeżeli stosowanie i wprowadzanie do obrotu tych odmian zatwierdzono na podstawie art. 20 rozporządzenia (WE) nr 1829/2003 Parlamentu Europejskiego i Rady z dnia 22 września 2003 r. w sprawie genetycznie zmodyfikowanej żywności i paszy i jeżeli odmiany te zostały zatwierdzone do włączenia do Wspólnego katalogu odmian gatunków roślin rolniczych ustanowionego przez dyrektywę Rady 2002/53/WE z dnia 13 czerwca 2002 r. w sprawie Wspólnego katalogu odmian gatunków roślin rolniczych, zmienioną rozporządzeniem nr 1829/2003.

Artykuł 26a dyrektywy Parlamentu Europejskiego i Rady 2001/18/WE z dnia 12 marca 2001 r. w sprawie zamierzonego uwalniania do środowiska organizmów zmodyfikowanych genetycznie i uchylającej dyrektywę Rady

36 Opubl.: http://curia.eu. 
90/220/EWG, zmienionej dyrektywą Parlamentu Europejskiego i Rady 2008/27/WE z dnia 11 marca 2008 r., nie pozwala państwu członkowskiemu na sprzeciwienie się w sposób ogólny uprawie na swoim terytorium takich organizmów genetycznie zmodyfikowanych z powodu zwłoki w przyjęciu środków dotyczących współistnienia upraw mających na celu zapobieżenie niezamierzonemu występowaniu organizmów genetycznie zmodyfikowanych $\mathrm{w}$ innych uprawach. 